\title{
The Parallels of Mobility and Exile in Chitra Banerjee Divakaruni's Before We Meet the Goddess: A Cosmopolitan Reading
}

\author{
Shobana Jeyasingam*, Manimangai Mani, Rosli Talif, Mohammad Ewan Awang \\ ${ }^{1}$ Faculty of Modern Languages and Communication, Universiti Putra Malaysia Jalan Upm, 43400 Serdang, Selangor, Malaysia
}

Corresponding Author: Shobana Jeyasingam, E-mail: shobana.jeyasingam@gmail.com

\section{ARTICLE INFO}

Article history

Received: February 21, 2018

Accepted: April 28, 2018

Published: September 01, 2018

Volume: 7 Issue: 5

Advance access: July 2018

Conflicts of interest: None

Funding: None

\begin{abstract}
Creating new cultures are equally relevant as to preserving one's identity and roots in this time and age. Kwame Anthony Appiah advocates that one be a rooted cosmopolitan - that we learn from each other's differences and celebrate diversity. And through this, one creates new cultures by connecting the cultures that one brings along and the cultures of the new environment. Therefore, being mobile through various forms of migration has opened up platforms for inclusivity through diversity. Waldron (1992) asserts that "all individuals are made up of multifarious cultural identities and already identify with an array of cultural obligations." The Indian diaspora is one community that embraces cosmopolitanism via mobility of culture and migration. Nonetheless, this paper will explore the conflicting notion of how mobility that provides a source of escapism for the characters in Chitra Banerjee Divakaruni's Before We Meet The Goddess eventually leads them to exile from each other. Mobility as a celebrated tenet of cosmopolitanism is embraced by three generations of women for various reasons and yet it has propelled them to a stance of rootlessness as opposed to the rooted cosmopolitan that they could have been. While most research of cosmopolitanism in Indian English fiction centres on the home and nation in developing cosmopolitan identity, this paper seeks to provide an alternate understanding to cosmopolitanism as to how mobility has inadvertently led these characters into exile (mainly from each other) and into a state of being rootless.
\end{abstract}

Key words: Cosmopolitanism, Rooted Cosmopolitanism, Mobility, Indian, Indian Diaspora, Rootless

\section{INTRODUCTION}

It was Diogenes in the $4^{\text {th }}$ century, who first called himself "a citizen of the cosmos" i.e. a cosmopolitan. Nonetheless, the ramblings of an Athenian vagrant who chose to announce himself as a citizen of the world was more to disassociate himself from the tensed political climate of then-Athens rather than proclaiming a cosmopolitan philosophy of any sorts. Denouncing oneself from any political belonging literally meant one had no nation-state to belong to and therefore even the genesis of cosmopolitanism has exile at its core. Having said that, the idea of being cosmopolitan, or as it has developed throughout the years from Diogenes to present-day society, has in its roots the notion of doing away with parochial roots and political fealty. The world is borderless and we who inhabit her should be devoid of partiality and preference of any sort.

Cosmopolitanism has received much scrutiny within academia in the past centuries. The disbanding of the European colonies in the twentieth century gave way to massive displacement in the Western world. A supposedly homogenous West was now home to many different people, cultures, and beliefs. Even so, Derick Mattern through his poems "The Whitewasher of Chora" and "Profiterol", puts forth the idea that exile and displacement are not only felt by those who are forced to leave their countries but also by marginalized minorities who often feel that their differences and distinctness could be whitewashed away. It is such an assertion that puts cosmopolitanism front and centre. Scholars like Kwame Anthony Appiah, Paul Gilroy, and Martha Nussbaum champion cosmopolitan ideals as being prominently pluralistic, encouraging the acceptance of differences, and seeing "humanity" as the significant core of one's identity. It is such contentions that can encourage a beautiful amalgamation of cultures and traditions that delineate a pluralistic society and cosmopolitan living. Brock (2013) posits that "being a cosmopolitan indicates that one is a person who is influenced by various cultures." Yet, Appiah (2006) also asserts that it is essential that one preserves one's vernacular identity while maintaining a cosmopolitan mindset.

Subsequently, as early displacement was mainly due to forced migration and slavery, the current trends have definitely shifted the focus from exile to migration. People across the world migrate to greener pastures in the hopes 
of economic independence, a better life, and as a beacon of hope that was never found where they were. Mobility is one aspect of cosmopolitanism that fits in the Indian diaspora. The Indians have traversed the entire space of the globe, starting off as merchants of the East, and when colonialism took over as indentured labourers in the Africas and West Indies, and to current day emigration mainly as a means of escaping poverty, extremism, familial disputes, and political differences.

How does mobility that ideally bring so much advancement and improvement to one's life take a different turn and result in detachment and exile? The premise of this paper is to dissect mobility within a cosmopolitan perspective and how moving into a better locality takes the characters on a journey of self-preservation and elevation of social status. Nonetheless, the proposition proffered here is that mobility that advances the lives of these three generations of women subsequently delivers them into exile, loneliness, and detachment from genuine familial bonds. While cosmopolitanism advocates the retaining of one's vernacular identity, these characters find themselves in an unbeknownst conundrum of exile and detachment. Being themselves and staying true to their roots become a colossal challenge. Hence, this paper seeks to proffer an alternate view to mobility and migration of the Indian diaspora within a cosmopolitan outlook in literary studies whereby the movement of these characters into their chosen spaces, while achieving the need for escape, results in the huge diminish of their roots and an extreme disconnect between three generations of women.

\section{MOBILITY IN BEFORE WE VISIT THE GODDESS}

As the focus dials up on the Indian diaspora, the term postcolonial is inherently present. Postcolonial criticism has along the way highlighted issues of the Indians at home as well as the Indian diaspora. Nonetheless, Amanda Anderson believes that postcolonial criticism has been "more attentive to situatedness than the word cosmopolitan that celebrates mobility, detachment, and voluntary identification" (Anderson, 2005). Mobility is one of the cruxes of cosmopolitanism as it is also a main defining feature of the Indian diaspora. The Indian diaspora exists on the idea of mobility that is sought out as a means of escapism, economic stability and financial freedom, and in some cases as a means of survival. In Chitra Banerjee Divakaruni's Before We Visit The Goddess, the central characters use mobility as a means of escapism that is very much centred within cosmopolitanism.

Before We Visit The Goddess is a tale masterfully wrought centering on three generations of women spanning a hefty six decades. The first protaganist is Sabitri Dasgupta. Her story begins as an old woman exiled from her daughter and granddaughter on the account of failed relationships and egoistic narcisism. It is this parallel existence of mobility and exile within the cosmopolitan view that that I would like to highlight. As much as it provides a buffer for a better life and greater prospects, mobility is predisposedly one step away from exile. A young Sabitri is introduced as living in a small village away from big-city Kolkata whose mother worked hard selling sweets. Seeing and experiencing poverty since young, Sabitri sought to better her life and in relation her family's as well.

"Sometimes she wrote things she needed to believe: I'm lucky to be in Kolkata, getting an education.

How many girls get this opportunity? Soon I'll get a great job. I'll earn enough money so my family

will never be hungry again.” (pg 11)

As noble the intentions and encouraging the reason behind mobility was for Sabitri, her upward scale eventually led to a more dismal situation. After getting herself involved with her rich patron's son, her innocent relations were frowned upon and she was thrown out of the house. Frantic and backed up the wall, she used her newfound courage and beauty to beguile her college master to eventually marry her and thus end her trials and tribulations. Yet, in her heart she knew that she had let go of her true self, and in desperation became something she never thought she would be: false. Her inner battles are depicted in her letter to her granddaughter as follows:

"Something in his voice, in those awkward, patting motions. A plan formed in my head. I held on

to it like a drowning woman. I did not allow myself to think of anything, of anyone else. Tara, can

you blame me? I lifted my face to him and smiled my prettiest, saddest, falsest smile." (pg 21)

Years later, Sabitri's daughter, Bela, follows in her mother's footsteps and learns a harsh lesson of her own. Mobility being the central issue that engulfs these women eventually leads them to exile. Bela, a somewhat rebellious daughter, who never could be the same after being indirectly involved in her parents' marital problems, finds herself in a situation like her mother. After falling in love with a pro-Communist student leader in her late teens, Bela decided to run away from home and migrate to America illegally and obviously without her mother's knowledge or consent.

Despite fully understanding the repercussions of running away - as well as any nineteen-year-old could have - Bela made the leap without too many qualms. Once again mobiliy provided some sort of escapism. Bela's husband, Sanjay, sought to escape political tension and even death by moving to America and Bela herself followed suit to seek a life with her beloved. Yet a better life that she sought came at the cost of exile from her mother; something she knew would happen and yet made the decision to leave.

"Would she really give up, for his sake, everything she was familiar with? Drop out of college? Cut

herself off from her mother - a wound never to be totally healed, because that's the kind of woman

her mother was? (pg 91)

History always repeats itself, they say, and the story unfolded yet another case of exile. What is important to note is that the exile I describe is not one that denotes a physical space or geographic location. I am looking to depict alienation of a familial nature whereby what is lost is love, family bond, affection, and most of all a legacy of what could have been.

Tara, the daughter of Bela Dewan, walks a similar path as did her mother and grandmother before. Born and bred 
in America, Tara definitely had no inkling of the trials and tribulations her grandmother faced as a young child. Neither was she privy to the difficulties her mother faced seeking the American Dream for she was just a child. Yet again, Tara left her mother just as Bela left hers. After a bitter divorce that resulted in Bela begging Sanjay to stay but to no avail, Tara stopped talking to both her parents as iterated in the excerpt below:

"Until he destroyed our family, at which point I stopped talking to him. I didn't talk to my mother much, either, after the divorce. The last had been two years ago, the night before the abortion."

(pg 126)

She moved away from both divorced parents and refused to maintain any contact with either. Her estrangement with her mother, particularly, led Tara into many misfortunes including failed relationships and even an abortion. Her mother was who she looked for in her toughest moments but she never knew to value the bond between a mother and daughter and gave up on contacting her mother only too easily:

"I'd called because I was scared. Because suddenly I wasn't sure if I was doing the right thing. But

I never got to talk to her. A man picked up at the other end. At first I thought it was a wrong

number because it was so late at night, but he told me it wasn't. I hung up then. Clearly, my

mother had moved on with her life. I needed to do the same." (pg 126)

Cultures and traditions are often discussed as local and rooted entities not mobile or global, thus, the cultural mobility experiments produce results that are rooted temporally and locally (Greenblatt, 2010). However, mobility as a cosmopolitan tenet does not only reflect a physical movement but also how culture and traditions should also be mobile as its believers are. Yet, when Sabitri, Bela, and Tara uprooted themselves in escaping poverty, a disapproving mother, and parents' divorce respectively, all three found themselves exiled from one another which resulted in much loss of love and familial bonds.

\section{MOBILITY AS A CAUSE OF ESTRANGEMENT IN BEFORE WE MEET THE GODDESS}

"The cosmopolitan patriot can entertain the possibility of a world in which everyone is a rooted cosmopolitan, attached to a home of one's own, with its own cultural particularities, but taking pleasure from the presence of other, different places that are home to other, different people" (Appiah, 1997). As Appiah discusses, rooted cosmopolitanism encourages one to embrace one's roots while soaking in the multicultural new order of accepting differences and celebrating diversity. The idea that mobility has provided the characters with the opportunity to forge ahead along the cosmopolitan route is apparent in their immediate escape from the troubles they sought to deliver themselves from. Sabitri escaped poverty, Bela eloped to her love, and Tara left her divorced parents.

Nonetheless, seeking the promised land for a better life did not see Bela in a position where she thrived in a newly generated acceptance of the diversity in her new homeland nor does Bela display a renewed love and allegiance to her Indian roots. She laments about how the quality of life was not up to what she had taught that she would have.

"As she watched them, it struck her that America might have saved their lives, but it had also diminished them." (pg 102)

Even the house that she and Sanjay had painstakingly saved up to buy had to be rented out to someone else to compensate for their struggles and financial difficulties, as is depicted here:

"Every so often, she had to stop, close her eyes, and breathe deep, so overcome was she with jealousy of the woman who would live here (in her house)." (pg 102)

All that trials and tribulations kept building and building in her until she started feeling suffocated and stuck in a lacklustre life:

"But everything she had tamped down, all her disappointments since - yes, for the first time she

admitted it - her marriage, swirled in her like a dust storm. She was stuck in a dingy apartment,

stuck in a dead-end job she hated, stuck under a load of unpaid loans so heavy that she'd probably

never be able to squirm out from under them and go back to college." (pg 107)

The bitter irony of the situation was that chasing the American dream did not necessarily deliver Bela into a more stable and secure life. Emigration provided Bela an escape but it also estranged her further from her mother, her family, her culture, and her roots. The act of eloping in itself was not an adequate representation of Indian or Eastern values but perhaps it could be brushed aside on the account of young love that is sometimes immature and blind. Nevertheless, Bela could not escape the shackles of a failed marriage and a separated family when her husband, Sanjay cheated on her and eventually divorced her. Throughout her years raising a family, Bela hardly contacted her mother, partly due to her husband's disapproval and partly due to her inability to uphold such values due to the hardships of her immigrant life.

In reality, despite many years in America, Bela herself never felt as if she belonged entirely. During those initial days Stateside, she was aware that "people stared at her routinely" but that "although it annoyed her, she accepted it as a cost of living in America." (pg117). Having said that, "despite her years in this country, she wasn't familiar enough with America to pick up on the signs." (pg152). Besides being alienated from her family and roots, Bela was never a "true" American herself. One could argue that she was perhaps indeed rootless.

\section{MOBILITY AS A CAUSE OF ROOTLESSNESS IN BEFORE WE MEET THE GODDESS}

Bela's daughter, Tara, grew up with almost zero knowledge of a grandmother back in India, of her roots and her identity.

"I was certain this person - whoever he might be - was nothing like me. I'd never been to India,

I didn't hang with Indians, I didn't even think of myself as Indian." (pg 120)

As soon as she finished school and her parents divorced, Tara left home and cut ties with her family. One could agree 
that for any child their parents' divorce can be heartbreaking and traumatizing in some instances. Yet Tara did not seek for solace and companionship with her mother to get over the ordeal that they were in fact facing together.

"In the mental conversations I can't seem to stop having with my mother (which are the only

conversations we have anymore), I ask,....” (pg 51)

It is clear in the story itself that Tara has cut herself off from her parents. She blames her father mainly for the divorce and is therefore clear with her bitterness towards him. Conversely, she surmised that her feelings toward her mother were "a more troublesome case" (pg 64). Tara also does not even know or vaguely remember her grandmother Sabitri, Bela's mother. In her attempt to blend in and live an American life, Bela inadvertently alienated herself and her daughter from her mother.

Consequently, Tara missed out on having a real relationship with her mother and grandmother. It can be seen in the way she connects with two complete strangers; Mrs Mehta (the woman she encountered while house-sitting) and $\mathrm{Mr}$ Venkatachalapati (the man she drove around while working at a driving agency); that Tara is indeed yearning for guidance and support from older, more experienced family members unbeknownst to her own self. Furthermore, her creating and having a bond with these older Indian individuals perhaps foreshadows or brings forth her desperate need for a cultural connection that could be a moral compass of some sorts in her life for she herself feels a sense of loss and incompleteness. Early in her young adulthood, Tara had gotten pregnant and had had to go through an abortion. In her terror and utmost desperation, she attempts to contact her mother but reconsiders at the last moment. A solid family support system and familial bonding are common traditional values of the Indian community. Having said that, the mobility that propelled Bela towards living an immigrant life also cost her daughter and her on missing out on having a strong support system during their difficult times.

Subsequently, Tara grew up in a completely Westernized manner with no basic understanding or appreciation for her roots, culture, values, and identity. It could be said that it was her parents who should have inculcated Indian values and taught her the Indian culture and traditions. Without all that, Tara had gone astray in her young adulthood, without any roots to hold onto and values to pave a life of principles.

"Far as I know, I've never been inside a temple. My father, who was a Communist in his youth, was dead against it. My mother had to fight him just to set up an altar in the kitchen, where a tiny ten-

armed goddess statue shared space with her spices. Because he was the fulcrum of my existence, I

grew up convinced religion was the opium of the people."

The excerpt above demonstrates the inexistent belief system that was inculcated in Tara as a young child. Her parents not teaching her religion and culture inadvertently caused her to become alienated and estranged from her roots. In their attempts to normalise their lives in America, culture and values became irrelevant and obsolete. As a result, Tara was not a celebrated case of East meets West's cultural hy- bridity; she became an anomaly of rootlessness and a personality devoid of core beliefs. In fact, her incongruity and lack of basic Indian flair puzzled Mr Venkatachalapathi as seen in his musings in the excerpt below:

"Pleased with this small victory, he allowed himself to observe the girl as she drove back the way

they had come, hunkered and sullen, without a word of gratitude. She intrigued the scientific part

of his mind. She was a puzzle, with her Indian features and Texan boots, her defiant piercings, the

skin stretched thin across her cheekbones and crumpled under the eyes. And that spiky hair, now

fallen limp as a child's over her forehead. He had read somewhere that it was a style that lesbians

affected. What kind of Indian family, even in America, would produce such a hybrid?"

Even to a simple man such as Mr V, Tara was an incongruity that could not be placed as East, West, or even a mix of both. She was an anomaly.

Even years later when Tara becomes an adult, perhaps more mature and secure enough to be married with a child, she never really grows into her skin as much as she could have.

"What is she watching so intently? I try to guess, though most of what I know about India is from

books and movies and the Internet." (pg 194)

Tara is one character who somehow never found, or acknowledged, or even felt slightly intrigued about her roots. No doubt she was born an American but one can never simply do away with one's origins and ancestry. Appiah demonstrates that one should embrace one's own roots while creating new cultures and traditions in new environments or geographic locations. Yet Tara never does so.

"I felt worse than usual because my mother had just given me three beautiful silk saris, her most

expensive ones, plus an elegant white woollen shawl,.... I don't think I'll ever use them, though -

they're not exactly my thing." (pg 198)

It is pretty saddening that Tara never got to experience the extent of the richness and gloriousness of her Indian roots. Saris are often handed down from generations to generations of Indian women as a sign of familial bond and a treasured symbol of womanhood. It is tradition and a wonderful part of the thriving Indian culture. Yet Tara did not understand the depth of the gesture from her mother. It is rather unfortunate that a character with such potential for rejuvenation of identity and redevelopment of personality is inadequate of such character growth. Then again one could argue that the mobility that propelled her mother, Bela, to immigrate to the US had inadvertently cost them. Tara's lack of cultural upbringing had resulted in her not being able to embrace or even indulge in her culture and roots from young and all the way into adulthood. She was completely distanced from India and Indian culture. Consequently, Tara was unable to create new cultural forms nor celebrate traditions of her family and ancestors. She, I believe, is a character that elucidates rootlessness and was never able to be a rooted cosmopolitan. 


\section{CONCLUSION}

"In the global system of cultural exchanges there are, indeed, somewhat asymmetrical processes of homogenization going on, and there are forms of human life disappearing. Neither of these phenomena is particularly new, but their range and speed probably is. Nevertheless, as forms of culture disappear, new forms are created, and they are created locally, which means they have exactly the regional inflections that the cosmopolitan celebrates. The disappearance of old cultural forms is consistent with a rich variety of forms of human life, just because new cultural forms, which differ from each other, are being created all the time as well." (Appiah, 1997).

Appiah asserts that in the course of cultural hybridization, old cultures are sometimes replaced by new cultures and this is part of what a cosmopolitan celebrates. A heteregoneous, multicultural community has at its heart cosmopolitan ideals and practices. In the case of Bela and Tara, breaking free from a homogenous environment, albeit not due to the truest of intentions, allowed them a form of escape. Mobility propelled Sabitri, Bela, and Tara away from their 'troubles'. Yet especially for Bela, in adapting to the new culture, a lot of who she is and where she came from were lost. As a result, she became estranged from her mother and motherland. Consequently, her daughter Tara grew up with no knowledge of her family and roots. Ironically, pluralism that is celebrated in a cosmopolitan society was not embraced by these women. In trying to fit in, Bela inadvertently lost her mother and daughter. She distanced herself from India and inexorably detached herself from her culture and roots. This predicament alienated her from her mother and her daughter from her. Three generations of women had suffered irrevocably and it could be surmised that it was forgetting one's roots that had resulted in such difficulties.

Therefore, in addressing mobility as a celebrated tenet of cosmopolitanism, while migration and movement of the masses to more provident places open avenues for people to be more accepting of others and uphold pluralistic values (Appiah, 2006), this paper sought to explicate how the very same mobility can also result in an alternate circumstance. In the hopes of upgrading and escaping the harsh realities of life, these characters pursued a change of abode to make their lives better. Subsequently, the mobility that they sought after eventually resulted in the collapse of their home institution. These characters were 3 women who were grandmother, mother, and granddaughter respectively. But in seeking a form of escapism from their troubles, they inadvertently detached themselves from each other. In short, in becoming more cosmopolitan, these characters' mobility indirectly resulted in their disassociation from each other, their roots, heritage, and traditions. Appiah and his principles of rooted cosmopolitanism advocate migration and mobility, upholding shared beliefs, accepting differences, and cultural heterogeneity as well as pluralistic values. It is also imperative that in being a cosmopolitan, one maintains and values one's vernacular identity and roots. These characters were unable to be part of a genuine pluralistic society as they themselves had turned their backs on their roots and identity as preserved by familial bonds. Nonetheless, despite seeking mobility in the hopes of escapism, these women were unable to embrace their own roots and in turn failed in attaining a rooted cosmopolitan identity.

\section{REFERENCES}

Anderson, A. (1998). Cosmopolitanism, universalism, and the divided legacies of modernity. CULTURAL POLITICS, 14, 265-289.

Appiah, K. A. (1997). Cosmopolitan patriots. Critical inquiry, 23(3), 617-639. https://doi.org/10.1086/448846

Appiah, K. A. (2010). Cosmopolitanism: Ethics in a world of strangers (issues of our time). WW Norton \& Company.

Beroš, M. (2016). Cosmopolitan Identity-historical origins and contemporary relevance. Tabula: časopis Filozofskog fakulteta, Sveučilište Jurja Dobrile u Puli, (14), 197-211.

Brock, G. (Ed.). (2013). Cosmopolitanism versus non-cosmopolitanism: critiques, defenses, reconceptualizations. OUP Oxford.

Divakaruni, C.B. (2016). Before We Visit the Goddess. New York, New York: Simon \& Schuster

Gilroy, P. (2005). Anew cosmopolitanism. Interventions, 7(3), 287-292. https://doi.org/10.1080/13698010500268049

Gilroy, P. (2005). Postcolonial melancholia. Columbia University Press.

Greenblatt, S. (2010). Cultural Mobility: A Manifesto. Cambridge University Press.

Kendall, G., Woodward, I., \& Skrbis, Z. (2009). The sociology of cosmopolitanism: Globalization, identity, culture and government. Springer.

Nussbaum, M. (1994). Patriotism and cosmopolitanism. The Cosmopolitan Reader, 155-162.

Nussbaum, M. C. (1997). Kant and stoic cosmopolitanism. Journal of political philosophy, 5(1), 1-25.

Waldron, J. (1991). Minority cultures and the cosmopolitan alternative. U. Mich. JL Reform, 25, 751.

Werbner, P. (2011). Paradoxes of postcolonial vernacular cosmopolitanism in South Asia and the diaspora. The Ashgate research companion to cosmopolitanism, 107-123. 